\title{
A Cure Rather than a Disease: Government Ownership and Minority Shareholder Protection
}

\author{
Mihail K. Miletkov* \\ University of New Hampshire, USA
}

The governments which undertake privatization of their state owned enterprises often maintain some ownership in the newly privatized firms. This paper examines the effect of the presence of the government as a minority shareholder on the protection of the minority shareholders in privatized firms. Consistent with the government's incentive to foster security market development and to enlist the support of the median-class voters for the privatization process we find that the government effectively monitors the controlling shareholders in the newly privatized firms and curbs their ability to expropriate the minority shareholders. Furthermore, the evidence suggests that minority government ownership acts as a substitute for the lack of alternative mechanisms for minority shareholder protection. (JEL: F30, G30, G32, G38)

Keywords: privatization, private benefits of control, government ownership, investor protection

\section{Introduction}

The privatization of state-owned enterprises (SOEs) is widely used by governments since the 1980 s, and continues to be a major priority for policy makers in a number of countries. Early studies of the

\footnotetext{
* Peter T. Paul College of Business and Economics, University of New Hampshire. Contact information: mihail.miletkov@unh.edu, 10 Garrison Ave., Durham, NH 03824. The author thanks James Linck, Harold Mulherin, Jeffry Netter, Annette Poulsen, and seminar participants at the University of New Hampshire, HEC Montreal, and the University of Georgia, for many helpful comments. The author also acknowledges the financial support of the Atkins Investment Center at the University of New Hampshire. All errors remain the responsibility of the author.
}

(Multinational Finance Journal, 2014, vol. 18, no. 1/2, pp. 1-41)

(C) Multinational Finance Society, a nonprofit corporation. All rights reserved. DOI: $10.17578 / 18-1 / 2-1$ 
privatization programs document that the privatization of SOEs is associated with significant increases in profitability, operating efficiency, and capital expenditures. ${ }^{1}$ Based on the finding that government ownership is associated with poorer firm performance many authors either explicitly or implicitly conclude that the optimal government ownership stake in newly privatized firms (NPFs) is zero. In this paper we argue that while government control may be inherently inefficient, there may be some benefit from having the government maintain a minority ownership stake in the NPFs. Specifically, we document that the presence of the government as a minority shareholder curbs the ability of controlling shareholders to extract private benefits of control from NPFs.

The incentives of the government to protect the minority shareholders in NPFs from expropriation by the controlling shareholders are consistent with the government's goal of using the privatization of SOEs to foster security market development. The relationship between privatizations and security market development is examined in a series of recent papers. Megginson et al. (2004) suggest that the development of a liquid stock market and an "equity culture" are among the major objectives of the privatizing governments. ${ }^{2}$ They find that the privatizing governments in countries with less developed capital markets are more likely to privatize their more profitable SOEs through share issue privatizations (SIPs) in order to foster security market development. Additionally, Jones et al. (1999) document that the privatizing governments consistently underprice SIPs, and favor domestic investors in the allocation of shares in order to induce the median-class voters to support and participate in the privatization process. Boutchkova and Megginson (2000) find that SIPs have significantly increased stock market liquidity and the number of shareholders in many countries. ${ }^{3}$ (2001)

1. For an excellent survey of the privatization literature see Megginson and Netter

2. The authors quote one member of the OECD's Privatization Working Group, “[T]he objective of privatizations had nothing to do with raising money for the budget, but solely for broadening the capitalistic base, getting people to become shareholders and private owners....[I]n other words, the objective was purely political to foster market economy and thus democracy."

3. However, the authors note that "the extremely large numbers of shareholders created by many share issue privatizations are not a stable ownership structure. For the 47 offers that initially yield over 250,000 shareholders, the total number of shareholders declines by 
A number of countries, however, did not experience the desired capital market development following the launch of their mass privatization programs. Atanasov, Ciccotello, and Gyoshev(2006) state that:

Like Russia and other Eastern European nations such as Czechoslovakia and Poland, Bulgaria engaged in mass privatization. The Bulgarian Big Bang was in 1998 and over a thousand firms were listed on the Bulgarian Stock Exchange. Similar to several other Eastern European transition economies, the Bulgarian market suffered after its opening from mass expropriation of minority shareholder wealth. Two-thirds of all Bulgarian firms were de-listed within three years (1999-2001) of their first trading on the Bulgarian Stock Exchange.

The failure of the mass privatization programs to spur the development of the equity markets in many developing countries is largely attributed to the lack of adequate legal and extra-legal institutions that curb the ability of the new controlling shareholders to extract private benefits of control at the expense of the minority shareholders. The present paper examines the role of government in curbing those benefits.

The private benefits of control represent corporate benefits that controlling shareholders receive above and beyond the benefits which accrue to them in proportion to their fractional ownership in the corporation. The existence of private benefits and minority shareholder expropriation in public companies is well documented in the finance literature. Dyck and Zingales (2004) estimate the magnitude of the private benefits of control in 39 countries, and find that on average corporate control is worth 14 percent of the equity value of a firm. They also document a negative relationship between capital market development and the private benefits of control. Johnson et al. (2000) find that tunneling, which is defined as the transfer of assets and profits out of the firm for the benefit of its controlling shareholders, is not restricted to emerging markets, but it quite commonly appears even in developed countries. The main forms of tunneling are self-dealing transactions such as outright theft, transfer pricing, excessive compensation, loan guarantees, asset sales, and dilution.

In this paper we argue that the privatizing governments have an 
incentive to curb the ability of the controlling shareholders to extract private benefits of control from the newly privatized firms (NPFs). The privatizing governments, which are attempting to foster security market development, have an incentive to curb the ability of the controlling shareholders to extract private benefits of control, because the extent of private benefits of control adversely affects security market development (Dyck and Zingales (2004)). Additionally, the theoretical model of Biais and Perotti (2002) and the empirical findings of Choi and Nam (1998), Jones et al. (1999), and Aussenegg (2000) suggest that the privatizing governments build political support by underpricing and preferentially allocating shares in the NPFs to the median-class voters. The government, therefore, has an incentive to protect the minority shareholders in the NPFs, because if these small shareholders were expropriated by the new controlling shareholders the government would most likely lose their votes in a subsequent election. The following quote from Megginson and Netter (2001) illustrates the above point: "Democratic governments are usually acutely aware of the political fallout that could result if small investors suffer losses on their SIP (share issue privatization) investments because of inadequate shareholder protection or insider dealings."

The government can pursue different strategies to curb the private benefits of control in the NPFs. For example, the government can implement new laws and/or strictly enforce the existing laws to increase the level of investor protection and reduce the benefits of control. Additionally, the government can set up a regulatory agency similar to the U.S. SEC to oversee the financial markets and to enforce the securities laws. These strategies, however, require considerable time and resources. A more efficient way, at least in the short-run, may be for the government to retain a minority ownership stake in the NPFs until adequate legal and extra-legal institutions are developed to protect the minority shareholders from the potential expropriation by the controlling shareholders. The government, as a minority shareholder, can be especially effective at monitoring the new controlling shareholders, because it has extensive knowledge of the operations of the NPFs, it does not face a free-rider problem, and has access to disciplinary powers that are not available to other shareholders. Additionally, while most governments may be reluctant to interfere with the actions of the new controlling shareholders, because such interference can signal a non-commitment to privatization, the government which acts to protect its rights as a minority shareholder may be more proactive in monitoring, since its actions are less likely to 
be interpreted as a non-commitment to privatization.

Examining the direct role of the government in curbing the private benefits of control is of great importance given the continuation of the privatization process in a number of countries. For instance, the governments in the emerging market countries, where the private benefits of control are especially large (Dyck and Zingales (2004)), might be able to increase the efficiency and profitability of their SOEs through privatization, and at the same time reduce the possibilities for minority shareholder expropriation by retaining some ownership in the privatized enterprises.

The following case illustrates that the presence of the government as a minority shareholder can curb the private benefits of control enjoyed by the controlling shareholders:

The Serbian government...ordered the arrest of Sreten Karic. ...Sreten - former chief executive officer of "Mobtel", is accused of fraud and tax evasion for 2.8 million euro, while he was in charge of the company. This happened through the acquisition of 79 luxurious apartments for 13 million euro, which were subsequently sold at a much lower price to the Karic family and other top officers in the company. In this manner, the government was defrauded since it is a shareholder in "Mobtel". The allegations against Bogolyub Karic... are for tax evasion and fraud through the tunneling of profits from "Mobtel" for the benefit of his firm in Cyprus "Usiko",...

The remainder of the paper proceeds as follows. Section 2 briefly reviews the literature on the private benefits of control. Section 3 presents the data and methodology employed in measuring the private benefits of control. Section 4 presents the empirical findings. Section 5 tests the robustness of the findings. Section 6 concludes.

\section{Literature Review}

The private benefits of control are the centerpiece of the recent literature in corporate governance. Shleifer and Vishny (1997) define corporate governance as a set of mechanisms through which the suppliers of finance assure themselves of receiving a return on their investment. The authors argue that good governance systems, which

4. StandardNews: Jan-19-2006. 
reduce the possibilities for diversion of corporate resources by the controlling shareholders, result in higher financial development.

La Porta et al. (1997, 1998, 2000a, 2000b, 2002) document that countries with good legal environments, which protect the potential financiers from the diversion of corporate resources by the controlling shareholders, have larger capital markets, higher dividend payout ratios, and higher corporate valuations. Dyck and Zingales (2004) directly test the relationship between the private benefits of control and financial development, and also find a negative relationship.

Atanasov (2005) examines the magnitude of the private benefits of control in a sample of Bulgarian NPFs. He documents that the majority owners of the Bulgarian NPFs extract more than 85 percent of firm value as private benefits of control.

\section{A. Sources of the Private Benefits of Control}

Given the importance of the private benefits of control, it is necessary to examine their exact nature. The finance literature presents three potential sources of private benefits of control: the psychological value of being in control, the consumption of perquisites, and the expropriation of the minority shareholders. The importance of the first two sources is well established in the finance literature (e.g., Aghion and Bolton (1992) and Jensen and Meckling (1976)). Recent studies, however, suggest that the minority shareholder expropriation component of the private benefits of control should not be overlooked.

La Porta, Lopez-de-Silanes, and Shleifer (1999) document that the majority of non-U.S. large publicly traded corporations have a controlling shareholder who owns at least 20 percent of the shares. The controlling shareholders usually exercise direct control over the corporations by being part of the top management as CEO or as chairman of the board. Furthermore, 75 percent of the corporations with controlling shareholders do not have another shareholder with at least 10 percent of the shares. Thus, the power of the controlling shareholders is largely uncontested, and is potentially used to expropriate the minority shareholders.

Johnson et al. (2000) study legal cases describing the expropriation of minority shareholders. The authors refer to the expropriation of minority shareholders with the term tunneling, which is defined as the transfer of assets and profits out of the firm for the benefit of its controlling shareholders. Contrary to what one might expect, tunneling 
is not restricted to emerging markets, but it quite commonly appears even in developed countries such as France, Italy, and Belgium. The main forms of tunneling are self-dealing transactions such as outright theft, transfer pricing, excessive compensation, loan guarantees, asset sales, and dilution (Johnson et al. (2000)).

\section{B. Measuring the Private Benefits of Control}

Lease, McConnell, and Mikkelson (1983) are the first to quantify the benefits of control. They estimate the value of corporate control by examining the market prices of the common stocks of companies that have two classes of common stocks outstanding, where the two classes have identical cash flow rights but different voting rights. The authors find that the class of common stock with superior voting rights trades on average at a 5.44 percent premium relative to the other class. The positive voting premium suggests that the controlling class of securityholders has an opportunity to receive a higher payoff than the non-controlling class of securityholders in at least some states of nature.

The voting premium does not directly measure the private benefits of control since it is calculated from prices set by minority investors who do not get to consume any private benefits. However, as Zingales (1995) suggests, the voting premium reflects the additional payments vote-holders expect to receive for their votes in case of a control contest, and these payments are positively related to the private benefits of control. Thus, the voting premium can be used as a proxy for the private benefits of control (Zingales (1995), Nenova (2003), and Doidge (2004)).

Barclay and Holderness (1989) employ an alternative approach to estimate the private benefits of control. They examine transactions involving transfers of controlling blocks in publicly traded corporations. The price per share that the acquirer of the controlling block pays reflects the cash flow benefits from his fractional ownership in the company and the private benefits he expects to extract from his controlling position in the firm. On the other hand, the market price of the stock on the day after the announcement of the block trade reflects only the cash flow benefits that non-controlling shareholders expect to receive in proportion to their fractional ownership in the company, in the presence of the new blockholder. Therefore, the difference between the price per share paid by the acquirer of the block and the price quoted in the market the day after the announcement of the block trade 
represents an estimate of the private benefits of control. Barclay, Holderness, and Sheehan (2001) use this approach to estimate the private benefits of control in a large sample of U.S. firms, and Dyck and Zingales (2004) use this approach to estimate the private benefits of control in a large sample of international firms.

In this study we follow the approach of Barclay and Holderness (1989) and measure the private benefits of control using the block premia. As discussed in Dyck and Zingales (2004) this approach is superior to the voting premia method since the latter is subject to several biases including the fact that many countries do not allow dual-class shares and companies with larger private benefits of control are more likely to issue dual-class shares.

\section{Data and Methodology}

Following Barclay and Holderness (1989) and Dyck and Zingales (2004) we estimate the block premia, which is our measure of the private benefits of control, as the difference between the price per share paid by the acquirer of a controlling block $\left(p_{b}\right)$ and the price quoted in the market two days after the sale's announcement $\left(p_{e}\right)$. The value of the private benefits of control as a percentage of the firm's equity value is computed by multiplying the premium paid per share times the number of shares in the block $\left(N_{b}\right)$ and dividing the result by the total market value of the firm's outstanding equity measured at the post announcement exchange price $\left(p_{e} N_{t}\right)$ :

Block premia (our proxy for the private benefits of control)

$$
=\frac{\left(p_{b}-p_{e}\right) N_{b}}{p_{e} N_{t}}
$$

The block premia can be either positive or negative with larger positive values indicating higher private benefits of control, and negative values indicating that the costs associated with being a controlling shareholder may outweigh any potential benefits from the controlling position in the firm.

The paper contributes to the privatization literature by documenting that the presence of the government as a minority shareholder in privatized firms curbs the ability of the controlling shareholders to expropriate the minority shareholders. Our analysis of the effects of 
government ownership on the private benefits of control is restricted to newly privatized firms. It is also possible to study the effects of minority government ownership on firms that were never under government control. By restricting the analysis to newly privatized firms, however, we can examine the effects of minority government ownership holding constant some important firm characteristics. Privatized firms, for example, are often substantially different from other firms in the economy, and the ability and the willingness of the government to monitor the controlling shareholders can be substantially different between privatized firms and firms that were never under government control.

Since the objective of the paper is to examine the role of government in curbing the private benefits of control in privatized firms, we begin the sample collection by compiling a list of privatized firms. We use the Securities Data Corporation (SDC) international mergers and acquisitions database to identify purchases of controlling blocks in the sample of publicly traded privatized firms. The analysis is restricted to purchases of blocks larger than or equal to 10 percent of the firm's stock during the period from 1990 to $2005 .{ }^{5}$

To ensure that the block trades involve the transfer of control rights a number of restrictions are imposed. ${ }^{6}$ First, we examine block trades that result in the acquirer moving from a position where he owns less than 20 percent of the shares to a position where he owns more than 20 percent of the shares. The 20 percent cutoff is also consistent with the seminal work by La Porta, Lopez-de-Silanes, and Shleifer (1999) who suggest that 20 percent ownership is typically sufficient for control.

Transactions between related parties such as the transfer of shares among subsidiaries of a common parent are excluded, as well as transactions where the acquirer involves management, since these may not convey changes in control. The next set of restrictions eliminates transactions where the price per share paid by the acquirer of the controlling block does not reflect the benefits of control. Excluded transactions are those identified by SDC as tender offers, spinoffs, recapitalizations, exchange offers, repurchases, acquisitions of

5. Dyck and Zingales (2004) also use the 10 percent cutoff and report that their estimates of the private benefits of control are unchanged when they employ a 15 percent cutoff.

6. This section follows the discussion in Dyck and Zingales (2004) since we employ the same set of restrictions. 
remaining interest, and block trades conducted through open market purchases.

In order to estimate the private benefits of control we need the price per share paid by the acquirer of the controlling block, and the price quoted in the market two days after the sale's announcement. This restricts the analysis to block trades with reported transaction values involving companies covered in the Datastream database. In addition, the analysis excludes transactions where the reported price per share is based on securities that could not be objectively valued such as warrants, convertible bonds, liabilities, as well as transactions that involve the exercise of options or include an option to purchase additional shares.

The final set of restrictions ensures that the block price and the post-announcement exchange price are not constrained by regulation. For example, there are laws requiring that all shareholders be treated equally in public offers. Thus, transactions where the controlling block is purchased as part of a public offer are excluded.

Company annual reports, the Worldscope Database, and company web sites provide government ownership information for the years of the block trades. Government ownership reflects direct ownership by the state as well as indirect state ownership through government controlled entities.

Our final sample consists of 54 block trades that are used to calculate the block premia, which is our proxy for the private benefits of control. The small sample size is mainly due to the constraint that the private benefits of control can be estimated only for the privatized firms that have block trades involving the transfer of control rights. Dyck and Zingales (2004) use the block premium to estimate the private benefits of control in publicly traded companies around the world. Their sample consists of 393 observations. Since our sample is limited to publicly traded privatized firms the sample size of 54 (approximately 14 percent of the sample in Dyck and Zingales (2004)) is not surprising. The average size of the block trades is approximately 39 percent of the firm's outstanding equity, and the average block premium is approximately 19 percent of the firm's equity value measured at the post announcement exchange price. 


\section{Results}

\section{A. Descriptive Statistics and Univariate Analysis}

Table 1 shows summary statistics on the block premia for different world regions, industries, and different acquirers. The descriptive statistics demonstrate that our sample is diverse across the different world regions, industries, and acquirer types. The countries from East Asia and the Pacific have the lowest average levels of private benefits of control while the countries from Latin America and the Caribbean have the highest average levels of private benefits of control. ${ }^{7}$ Regarding the different industries, the firms in retail trade have the lowest while the firms in mining have the highest average levels of private benefits of control. Finally, when the acquirer of the controlling block is a subsidiary the associated private benefits of control are the highest. ${ }^{8}$

The minimum and maximum values of the block premia reported in table 1 illustrate that there are a few extreme observations in our dataset. Minimum values of -40 percent and maximum values of over 100 percent for the block premia are also reported in Dyck and Zingales (2004) for several countries in their sample. In order to ensure that these outliers are not driving our results, in the robustness section of the paper we re-estimate our main regressions firstly by dropping all observations where the block premia are less than -40 percent or greater than 100 percent, and secondly by winsorizing the block premia at the 10 percent level. ${ }^{9}$

Table 2 presents descriptive statistics on the government's percentage ownership in the sample firms for the years of the block trades. The average government ownership stake in the target firms is approximately 19 percent. In 14 out of the 54 block trades the government has no ownership stake in the target firms. In 24 of the

7. The negative average value of control ( -10.57 percent) for East Asia and the Pacific indicates that in these countries the costs associated with being a controlling shareholder for example, being less than optimally diversified and engaging in costly monitoring activities - may outweigh any potential benefits from the controlling position.

8. We note, however, that the median value of the block premia is only 2.91 percent when the acquirer of the controlling block is a subsidiary. The maximum value of 248.72 percent, reported in the next to last column, suggests that the large difference between the mean ( 49.14 percent) and the median ( 2.91 percent) is due to a few extreme observations.

9. Our main results are robust to these alternative specifications. 
TABLE 1. Summary statistics on the block premia.

\begin{tabular}{|c|c|c|c|c|c|c|}
\hline & Mean & Median & St. Dev. & Min & Max & N. Obs. \\
\hline \multicolumn{7}{|l|}{ By region } \\
\hline $\begin{array}{l}\text { East Asia and } \\
\text { the Pacific }\end{array}$ & -10.57 & -11.03 & 20.37 & -55.56 & 36.25 & 14 \\
\hline $\begin{array}{l}\text { Eastern Europe } \\
\text { and Central Asia }\end{array}$ & 25.73 & 8.37 & 41.52 & -11.64 & 138.69 & 12 \\
\hline $\begin{array}{l}\text { Latin America } \\
\text { and the Caribbean }\end{array}$ & 65.56 & 8.2 & 117.13 & -46.74 & 248.72 & 8 \\
\hline $\begin{array}{l}\text { Middle East and } \\
\text { North Africa }\end{array}$ & 10.85 & 20.31 & 36.64 & -46.46 & 42.17 & 5 \\
\hline North America & 6.1 & 6.1 & & 6.1 & 6.1 & 1 \\
\hline South Asia & 3.23 & 2.91 & 7.15 & -7.41 & 14.11 & 6 \\
\hline Western Europe & 31.4 & 29.09 & 35.31 & -9.57 & 95.5 & 8 \\
\hline \multicolumn{7}{|l|}{ By industry } \\
\hline Mining & 40.07 & 11.37 & 66.38 & -1.16 & 138.69 & 4 \\
\hline Manufacturing & 21.85 & -1.62 & 63.29 & -46.46 & 215.77 & 16 \\
\hline $\begin{array}{l}\text { Transportation } \\
\text { and pub. utilities }\end{array}$ & 28.62 & 6.34 & 69.94 & -46.74 & 248.72 & 17 \\
\hline Retail trade & -7.47 & -11.64 & 10.8 & -15.56 & 4.8 & 3 \\
\hline $\begin{array}{l}\text { Finance, insurance, } \\
\text { and real estate }\end{array}$ & 3.79 & 4.82 & 27.89 & -55.56 & 44.03 & 10 \\
\hline Services & 1.07 & 2.41 & 6.34 & -7.41 & 6.86 & 4 \\
\hline \multicolumn{7}{|c|}{ By acquirer's public status } \\
\hline Government & 36.36 & 36.36 & e & 36.36 & 36.36 & 1 \\
\hline Joint venture & -46.74 & -46.74 & . & -46.74 & -46.74 & 1 \\
\hline Private & 11.75 & 4.8 & 40.03 & -46.46 & 138.69 & 33 \\
\hline Public & 16.37 & 1.78 & 45.15 & -55.56 & 95.5 & 9 \\
\hline Subsidiary & 49.14 & 2.91 & 97.19 & -11.03 & 248.72 & 10 \\
\hline
\end{tabular}

Note: The block premia are calculated as the difference between the price per share paid for the control block and the price on the Exchange two days after the announcement of the control transaction, multiplied by the number of shares in the block and divided by the total market value of the firm's outstanding equity measured at the post announcement exchange price. All the numbers are expressed as percentages.

block trades the government has a minority ownership stake, which implies that the government's ownership stake after the block trade is smaller than the ownership stake held by the acquirer of the controlling block. Finally, in 16 of the block trades the government is the largest 
TABLE 2. Summary statistics on government ownership.

\begin{tabular}{lcccccc}
\hline $\begin{array}{l}\text { Government Ownerhsip } \\
\text { Percentage }\end{array}$ & Mean & Median & St. Dev. & Min & Max & N. Obs. \\
\hline $\begin{array}{l}\text { Gvmnt is not a } \\
\text { shareholder }\end{array}$ & - & - & - & - & - & 14 \\
$\begin{array}{l}\text { Gvmnt is a minority } \\
\text { shareholder }\end{array}$ & 15.86 & 12.75 & 10.42 & 0.1 & 40 & 24 \\
$\begin{array}{l}\text { Gvmnt is the largest } \\
\text { shareholder }\end{array}$ & 41.58 & 46 & 9.61 & 26.12 & 55 & 16 \\
Full Sample & 19.37 & 13.6 & 18.08 & - & 55 & 54 \\
\hline
\end{tabular}

Note: The table presents summary statistics on the government's percentage ownership in the sample firms for the years of the block trades. Government ownership reffects direct ownership by the state as well as indirect state ownership through government controlled entities. Government is not a shareholder if the government's ownership stake after the block trade is zero. Government is a minority shareholder if the government's ownership stake after the block trade is smaller than the ownership stake held by the acquirer of the controlling block. Government is the largest shareholder if the government's ownership stake after the block trade is larger than the ownership stake held by the acquirer of the controlling block. All the numbers are expressed as percentages.

shareholder, which implies that the government's ownership stake after the block trade is larger than the ownership stake held by the acquirer of the controlling block. The average government ownership stake in the firms where the government is a minority (largest) shareholder is approximately 16 (42) percent.

Table 3 compares the average private benefits of control in firms where the government is not a minority shareholder to the average private benefits of control in firms where the government is a minority shareholder or is the largest shareholder. On average, the benefits of control in NPFs with no government ownership are 67.40 percent. This number is significantly larger than the average value of control (14 percent) reported in Dyck and Zingales (2004). Privatized companies are often located in developing countries with lower levels of investor protection, which can partly explain the large private benefits of control in these firms. Furthermore, the existence of very large private benefits of control in privatized firms is also documented in several prior studies. For example, Dyck and Zingales (2004) report that the average value of control in a sample of Brazilian privatized firms is 129 percent, and Atanasov (2005) finds that the private benefits of control in a sample of Bulgarian NPFs exceed 85 percent of firm value. 
TABLE 3. Government minority ownership and the private benefts of control. (univariate test)

\begin{tabular}{lcccccc}
\hline Block Premium & Mean & Median & St. Dev. & Min & Max & N. Obs. \\
\hline $\begin{array}{l}\text { Gvmnt is not a } \\
\text { shareholder }\end{array}$ & 67.4 & 33.64 & 83.9 & -11.04 & 248.72 & 14 \\
$\begin{array}{l}\text { Gvmnt is a minority } \\
\text { shareholder }\end{array}$ & $-1.59^{\mathrm{a}}$ & -1.86 & -55.56 & -95.5 & 95.5 & 24 \\
$\begin{array}{l}\text { Gvmnt is the largest } \\
\text { shareholder }\end{array}$ & $6.92^{\mathrm{a}}$ & 2.91 & 21.24 & -21.01 & 65.88 & 16 \\
$\begin{array}{l}\text { Total } \\
18.82\end{array}$ & 3.26 & 56.32 & -55.56 & 248.72 & 54 \\
\hline
\end{tabular}

Note: The table presents summary statistics on the block premia for the three categories of government ownership, as well as the results from two-sample mean comparison tests. The block premia are calculated as the difference between the price per share paid for the control block and the price on the Exchange two days after the announcement of the control transaction, multiplied by the number of shares in the block and divided by the total market value of the firm's outstanding equity measured at the post announcement exchange price. Government ownership reffects direct ownership by the state as well as indirect state ownership through government controlled entities. Government is not a shareholder if the government's ownership stake after the block trade is zero. Government is a minority shareholder if the government's ownership stake after the block trade is smaller than the ownership stake held by the acquirer of the controlling block. Government is the largest shareholder if the government's ownership stake after the block trade is larger than the ownership stake held by the acquirer of the controlling block. All the numbers are expressed as percentages. a-significant at $1 \%$ level; b-significant at $5 \%$ level; c-significant at $10 \%$ level.

Table 3 further documents that when the government is a minority shareholder the average private benefits of control are -1.59 percent. The significant difference between the two categories - when the government is not a shareholder and when the government is a minority shareholder - suggests that the presence of the government as a minority shareholder curbs the controlling shareholder's ability to extract private benefits of control. Furthermore, the negative value of the benefits of control in firms with minority government ownership implies that the costs of being a controlling shareholder in these firms outweigh the benefits of the controlling position. This is consistent with the interpretation that the block discounts compensate the controlling shareholders for incurring significant risk-bearing costs due to the large size of their stakes, and for engaging in costly monitoring activities, which lower agency costs and increase cash flows for all shareholders.

Finally, the univariate analysis in table 3 indicates that the private benefits of control in NPFs where the government is the largest 
shareholder, although significantly smaller than in NPFs with no government ownership, are still positive. One potential interpretation of this finding is that these firms, which are still under government control, are not actively scrutinized by the financial markets and may still have access to government subsidies (Megginson and Netter (2001)), all of which may create possibilities for insider self-dealing. ${ }^{10}$

The results from table 3 are, however, subject to an omitted variable bias. Specifically, we need to control for factors affecting both the private benefits of control measure and the government ownership. In the next section we use multivariate regression analysis to account for the potential endogeneity.

\section{B. Multivariate Analysis}

We control for several deal, firm, and country-specific characteristics that can bias our estimates. Prior research documents that private placements and share issue privatizations (SIPs) are often made at substantial discounts relative to the post-announcement exchange price. ${ }^{11}$ Doidge (2004) finds that cross-listing on a U.S. exchange reduces the controlling shareholder's ability to extract private benefits. Additionally, the transfer of blocks larger than 50 percent carries higher control potential than the transfer of smaller blocks, and the presence of another large shareholder can potentially reduce the extent to which the controlling shareholder can exercise control. We account for the effect of the above deal and firm characteristics by including the private placement, privatization deal, U.S. crosslisting, absolute majority stake, and another large shareholder (who owns more than 20 percent of the outstanding shares and is not the government) dummy variables.

Many countries require the acquirers of large blocks to make a tender offer to all remaining shareholders. We control for the effect of the anticipated tender offer on the post-announcement exchange price by including the mandatory tender offer requirement dummy variable that equals one if the transaction triggers the mandatory tender offer requirement, and zero otherwise. Arguably, the most important determinant of the ability of the controlling shareholders to extract private benefits of control is the protection of the minority shareholders'

10. Essentially, the firm's insiders may tunnel resources out of the firm with the implicit expectation that the government will not allow the firm to fail.

11. See Hertzel and Smith (1993), Jones et al. (1999) and Barclay, Holderness, and Sheehan (2001). 
rights provided by the legal system. We include the antidirector, anti-self-dealing, and rule of law indices to control for differences in the legal environments across countries. ${ }^{12}$

Finally, the main criticism of the Barclay and Holderness (1989) measure of the private benefits of control is that the premium paid for the control block reflects the value of control, as well as other aspects of the control transaction such as the seller's bargaining power. To address this concern, we include two deal characteristics capturing differences in the extent of the seller's bargaining power. ${ }^{13}$ First, if the company is in financial distress the seller is more likely to be forced to sell, and his bargaining power is lower. We proxy for financial distress by including a dummy variable that equals one if the earnings per share are zero or negative in the year of the block trade or the year preceding the block trade, and zero otherwise. Second, the selling shareholder in firms that can be acquired by foreigners has relatively higher bargaining power due to the increased competition. We control for this by inserting a dummy variable that equals one if the acquirer of the controlling block is foreign, and zero otherwise.

Including all the control variables discussed above reduces the likelihood that our results are subject to an omitted variable bias. However, given our small sample size, including all these covariates also reduces the power of our empirical tests. ${ }^{14}$ The sample size also leads to concerns that a few outliers can significantly affect our results. We address this issue in the robustness section of the paper where we re-estimate our main regressions first by winsorizing the data and second by dropping potential outliers. Finally, with small sample size asymptotic inference may be unreliable. In order to address this concern, in unreported analysis we follow Kogan (2010) and use bootstrapping to determine the statistical significance of our estimated coefficients. ${ }^{15}$ All of the empirical results from the subsequent

12. The indices are derived from La Porta et al. (1998), Pistor, Raiser, and Gelfer (2000), and Djankov et al. (2008).

13. Dyck and Zingales (2004) also employ these variables to control for differences in the extent of the seller's bargaining power.

14. This introduces a bias against us finding a significant relation between minority government ownership and the private benefits of control.

15. We use 100 bootstrap replications since Efron and Tibshirani (1986) suggest that in most situations performing 50-200 replications is adequate. Increasing the number of replications beyond 100 does not alter our results. 
regression analysis are robust to these alternative estimations.

Before proceeding with the multivariate regression analysis we examine the correlation coefficients between the independent variables. A high degree of correlation between the regressors can lead to concerns about multicollinearity. Table 4 illustrates that most of the correlation coefficients between the independent variables are relatively low, which alleviates the potential concerns about multicollinearity. ${ }^{16}$

Tables 5 and 6 present the results from the multivariate regressions examining the relationship between the private benefits of control and the presence of the government as a minority shareholder controlling for the deal, firm, and country-specific characteristics. We estimate the following general regression model ${ }^{17}$ :

Block premium $=\beta_{0}+\beta_{1}$ Government is a minority shareholder $+\beta_{2}$ Government is the largest shareholder $+\beta_{3}$ Private placement $+\beta_{4}$ Absolute majority stake $+\beta_{5}$ Privatization deal $+\beta_{6}$ Another large shareholder + $\beta_{7}$ Mandatory tender offer requirement $+\beta_{8}$ US crosslisting $+\beta_{9}$ Foreign acquirer $+\beta_{10}$ Financial distress $+\beta_{11}$ Investor protection indices $+\varepsilon$

In table 5 we introduce sequentially the deal, firm, and country-specific characteristics. Model 1 in table 5 introduces the deal-specific characteristics (private placement, privatization deal, absolute majority stake, and foreign acquirer). Model 2 examines the effects of the firm-specific characteristics (U.S. crosslisting, another large shareholder, and financial distress). In models 3 through 6 we include controls for the effects of the various country-specific characteristics (mandatory tender offer requirement, antidirector, anti-self-dealing, and rule of law indices).$^{18}$ In table 6 we include simultaneously all the deal, firm, and country-specific characteristics. Across all models, the estimated coefficient on the government is a minority shareholder dummy variable is negative and significant. These results support our main hypothesis that the presence of the government as a minority

16. The highest correlation coefficient is 0.67 .

17. All variables used in the paper are described in the Appendix.

18. When we include the rule of law index we lose two observations since the index is not available for Morocco. 


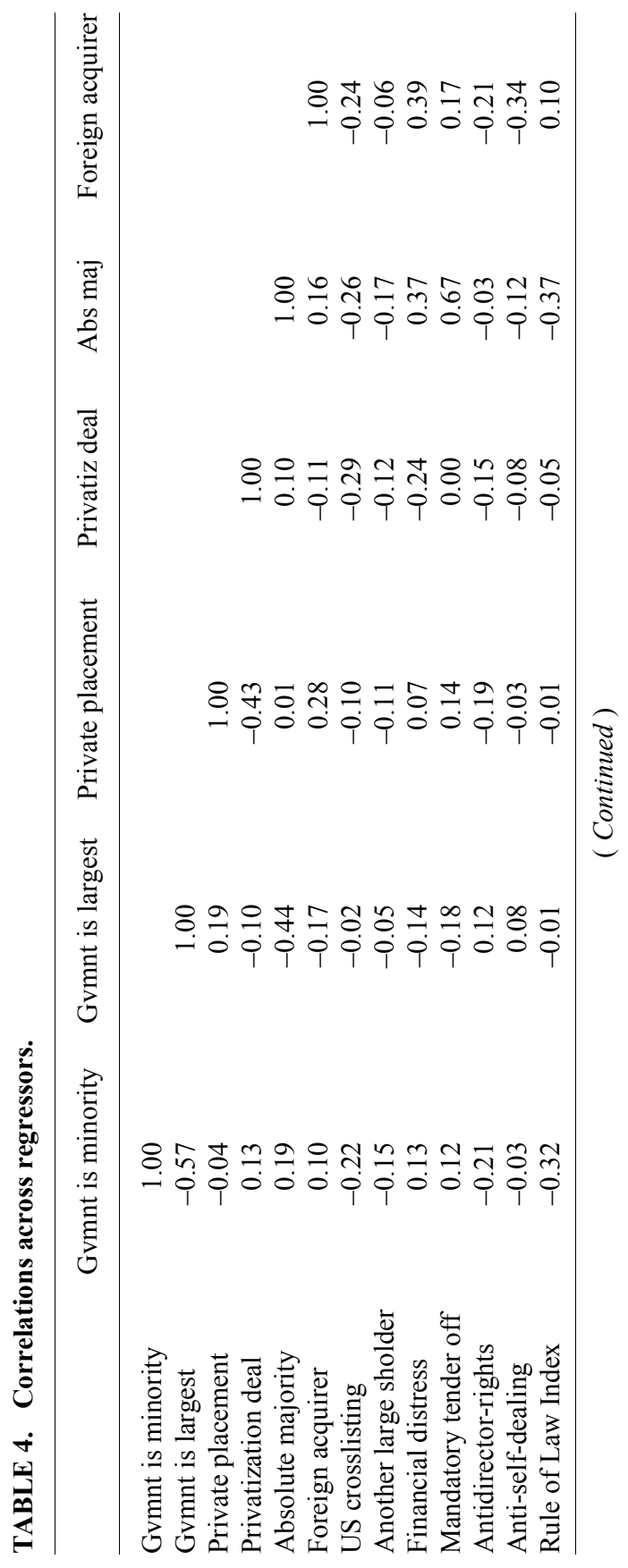




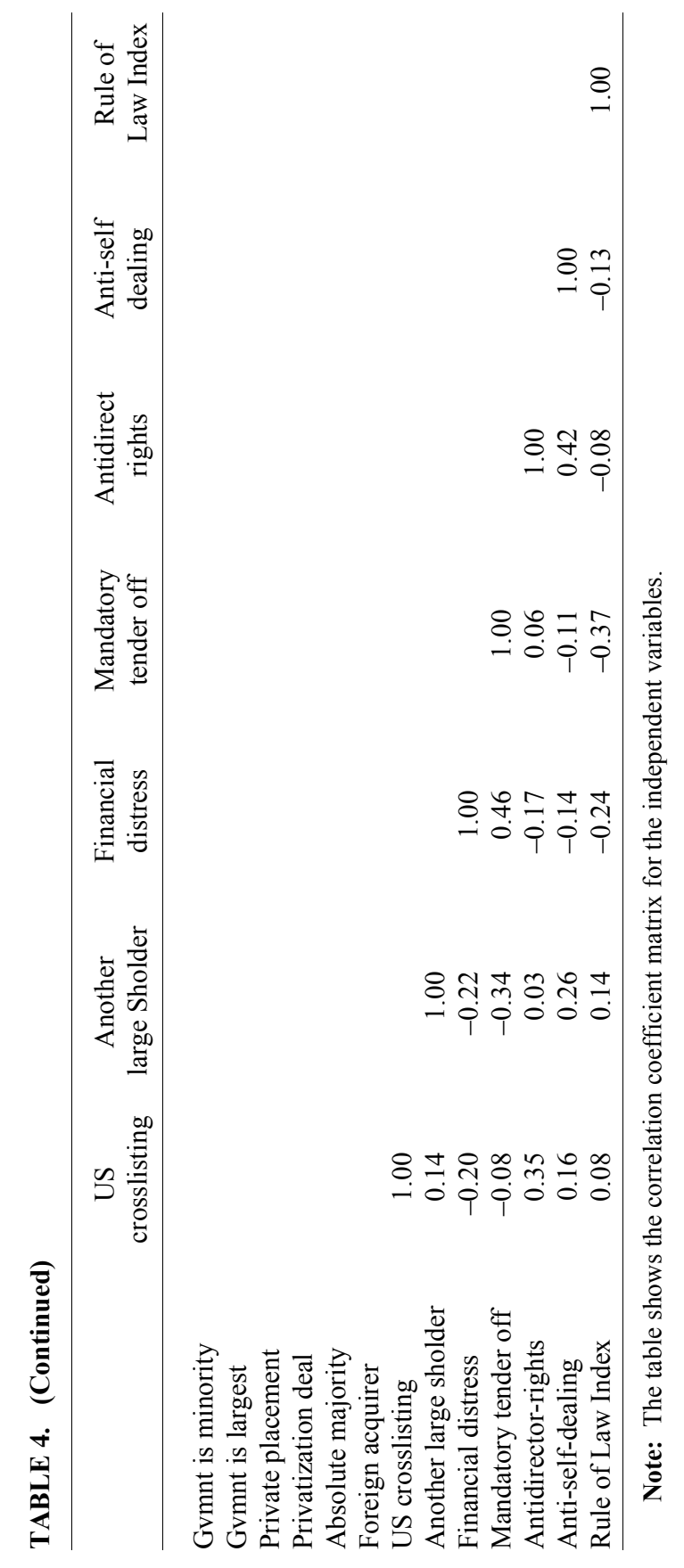




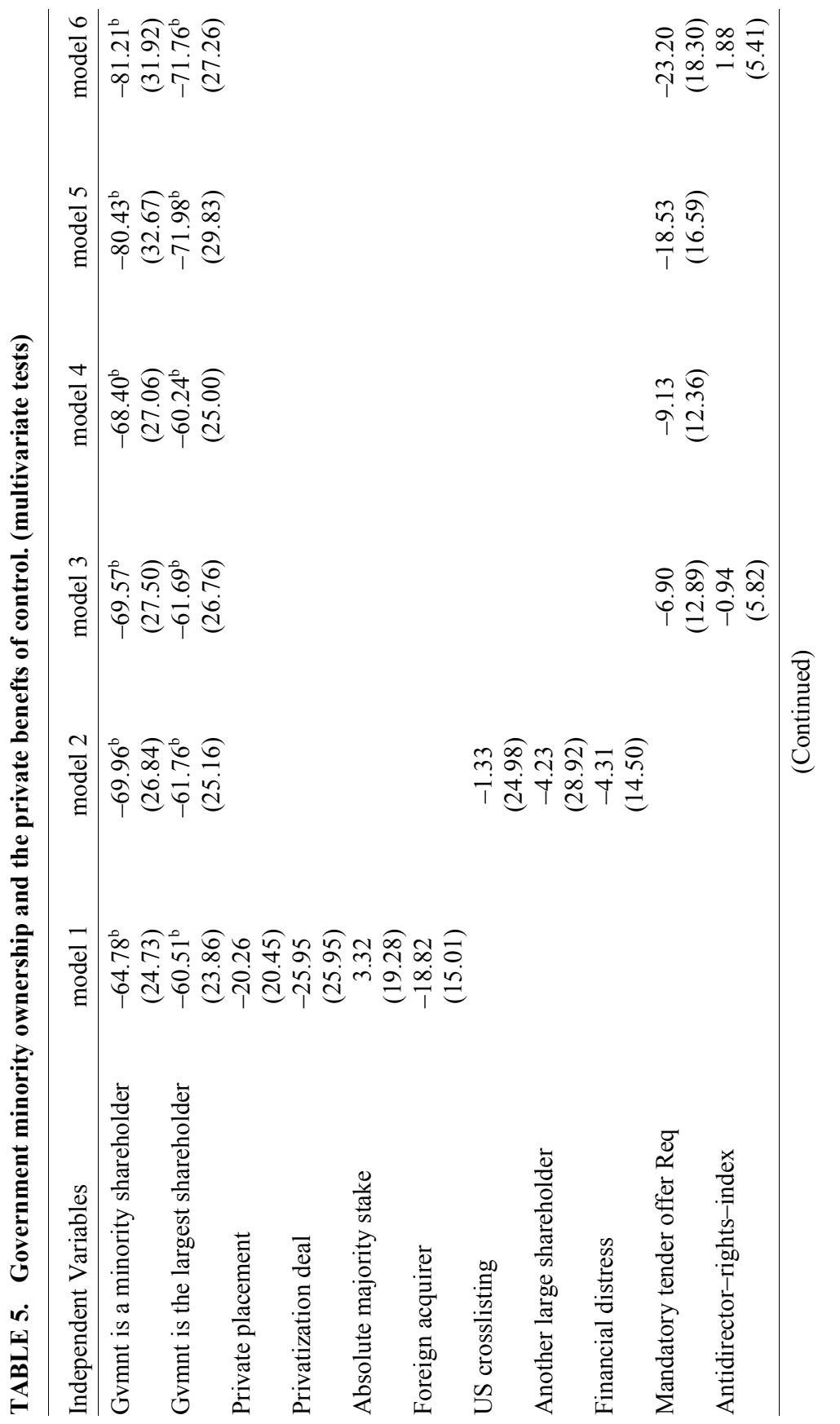




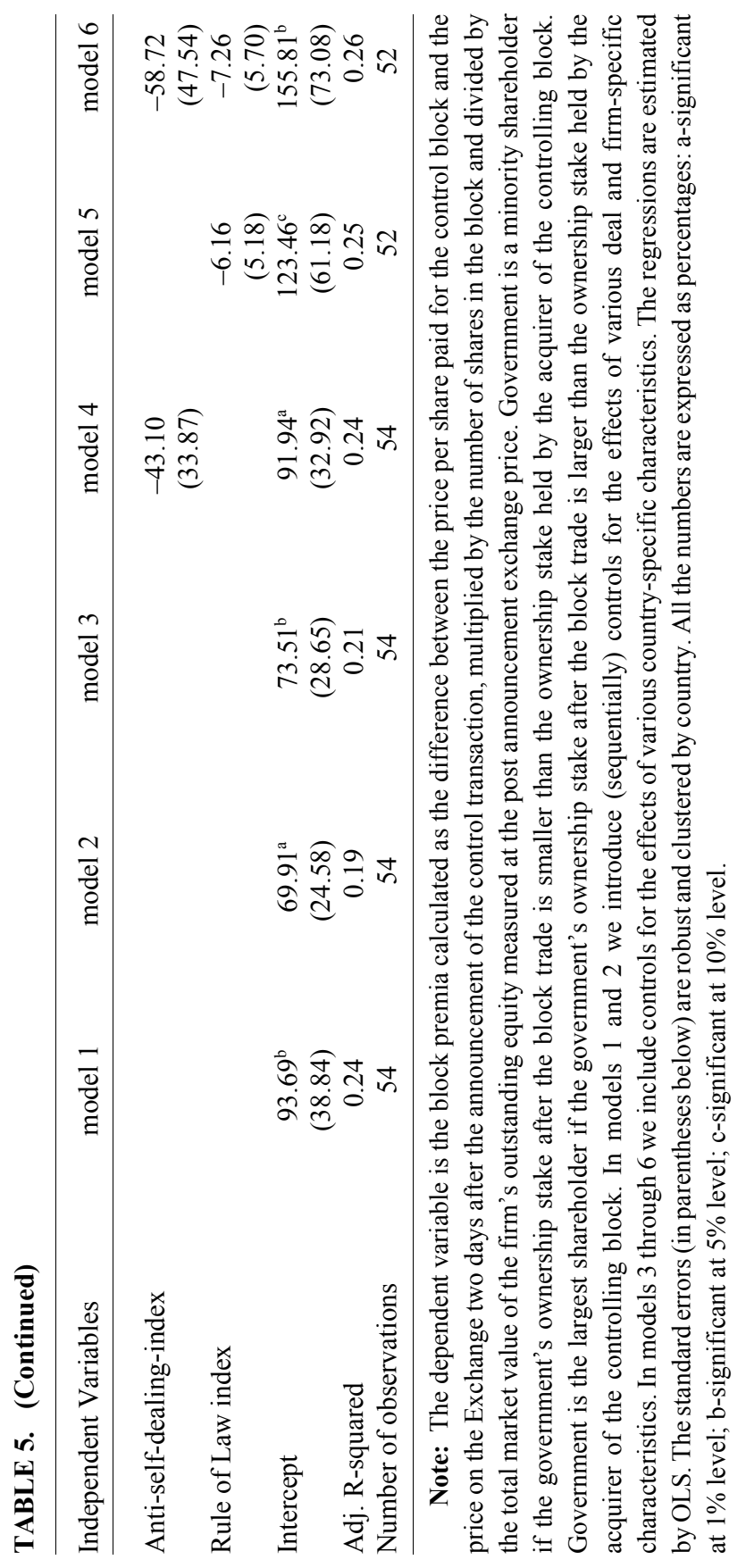


TABLE 6. Government minority ownership and the private benefts of control. (multivariate tests)

\begin{tabular}{|c|c|c|c|c|}
\hline Independent Variables & model 1 & model 2 & model 3 & model 4 \\
\hline \multirow[t]{2}{*}{ Gvmnt is a minority shareholder } & $-71.96^{\mathrm{a}}$ & $-66.70^{\mathrm{a}}$ & $-87.16^{\mathrm{a}}$ & $-86.95^{\mathrm{a}}$ \\
\hline & $(26.11)$ & $(24.09)$ & $(31.49)$ & $(29.51)$ \\
\hline \multirow[t]{2}{*}{ Gvmnt is the largest shareholder } & $-66.44^{\mathrm{a}}$ & $-64.57^{a}$ & $-83.86^{\mathrm{b}}$ & $-83.74^{\mathrm{a}}$ \\
\hline & $(24.10)$ & $(21.34)$ & $(31.60)$ & $(24.40)$ \\
\hline \multirow[t]{2}{*}{ Private placement } & -35.90 & -22.82 & -30.34 & -27.64 \\
\hline & $(24.35)$ & $(16.48)$ & $(21.70)$ & $(20.75)$ \\
\hline \multirow[t]{2}{*}{ Privatization deal } & -39.91 & -35.98 & -40.01 & $-42.07^{c}$ \\
\hline & $(26.11)$ & $(24.04)$ & $(25.06)$ & $(21.22)$ \\
\hline \multirow[t]{2}{*}{ Absolute majority stake } & 3.23 & 4.36 & -5.59 & -8.60 \\
\hline & $(28.08)$ & $(27.02)$ & $(29.45)$ & $(27.15)$ \\
\hline \multirow[t]{2}{*}{ Foreign acquirer } & -21.38 & -29.66 & -13.30 & -22.50 \\
\hline & $(17.93)$ & $(18.14)$ & $(17.60)$ & $(17.91)$ \\
\hline \multirow[t]{2}{*}{ US crosslisting } & -19.21 & -17.73 & -33.60 & -31.26 \\
\hline & $(27.39)$ & $(22.60)$ & $(30.88)$ & $(26.03)$ \\
\hline \multirow[t]{2}{*}{ Another large shareholder } & -14.80 & -4.27 & -18.73 & -8.45 \\
\hline & $(25.17)$ & $(23.49)$ & $(25.12)$ & $(25.09)$ \\
\hline \multirow[t]{2}{*}{ Financial distress } & -10.44 & -4.83 & -15.65 & -15.49 \\
\hline & $(19.48)$ & $(17.98)$ & $(17.47)$ & $(17.58)$ \\
\hline \multirow[t]{2}{*}{ Mandatory tender offer Req } & -3.83 & -8.13 & -12.93 & -11.90 \\
\hline & $(18.45)$ & $(16.44)$ & $(21.93)$ & $(22.90)$ \\
\hline \multirow[t]{2}{*}{ Antidirector-rights-index } & -5.58 & & & -1.01 \\
\hline & $(7.93)$ & & & $(8.15)$ \\
\hline \multirow[t]{2}{*}{ Anti-self-dealing-index } & & -65.22 & & -68.80 \\
\hline & & $(40.38)$ & & $(52.20)$ \\
\hline \multirow[t]{2}{*}{ Rule of Law index } & & & -6.55 & -7.66 \\
\hline & & & $(4.88)$ & $(5.05)$ \\
\hline \multirow[t]{2}{*}{ Intercept } & $137.31^{\mathrm{a}}$ & $147.77^{\mathrm{a}}$ & $180.38^{\mathrm{a}}$ & $228.89^{a}$ \\
\hline & $(47.61)$ & $(43.74)$ & $(65.32)$ & $(73.65)$ \\
\hline Adj. R-squared & 0.19 & 0.24 & 0.22 & 0.25 \\
\hline Number of observations & 54 & 54 & 52 & 52 \\
\hline
\end{tabular}

Note: The dependent variable is the block premia calculated as the difference between the price per share paid for the control block and the price on the Exchange two days after the announcement of the control transaction, multiplied by the number of shares in the block and divided by the total market value of the firm's outstanding equity measured at the post announcement exchange price. Government is a minority shareholder if the government's ownership stake after the block trade is smaller than the ownership stake held by the acquirer of the controlling block. Government is the largest shareholder if the government's ownership stake after the block trade is larger than the ownership stake held by the acquirer of the controlling block. In models 1 through 3 we introduce (sequentially) the anti-director, anti-self-dealing, and rule of law indices, which control for differences in the legal environments across countries. In model 4 we include all 3 indices simultaneously. The regressions are estimated by OLS. The standard errors (in parentheses below) are robust and clustered by country. All the numbers are expressed as percentages, a-significant at $1 \%$ level; b-significant at $5 \%$ level; c-significant at $10 \%$ level. 
shareholder curbs the ability of the controlling shareholders to extract private benefits of control. These results should be contrasted with Dyck and Zingales (2004) who find that "[c]ontrary to expectations, the presence of another large shareholder has a positive effect on the [block] premium, but this is not statistically significant." Our study suggests that when the other shareholder is the government, the benefits of control are significantly lower. The majority of the control variables have the expected signs, but are not significant at conventional levels.

In table 7 we repeat the tests from table 6, but add the government's percentage ownership as a minority shareholder to examine whether the magnitude of the government's shareholdings affects the ability of the controlling shareholders to extract private benefits of control. We estimate the following regression equation:

Block premium $=\beta_{0}+\beta_{1}$ Government is a minority shareholder $+\beta_{2}$ Government's \% ownership as a minority shareholder $+\beta_{3}$ Government is the largest shareholder $+\beta_{4}$ Private placement $+\beta_{5}$ Absolute majority stake $+\beta_{6}$ Privatization deal $+\beta_{7}$ Another large shareholder $+\beta_{8}$ Mandatory tender offer requirement $+\beta_{9}$ US crosslisting $+\beta_{10}$ Foreign acquirer $+\beta_{11}$ Financial distress $+\beta_{12}$ Investor protection indices $+\varepsilon$

Table 7 documents that after controlling for the presence of the government as a minority shareholder, the larger government shareholdings do not result in larger decreases in the private benefits of control. ${ }^{19}$ This result indicates that a minority stake, regardless of its size, provides the government with both the incentive and the ability to curb the self-dealing actions of the controlling shareholder.

\section{Government Ownership and Minority Shareholder Protection}

Several studies document that the level of investor protection in the country significantly affects the success of privatizations (Omran (2004), Boubakri, Cosset, and Guedhami (2005), Choi and Nam

19. This result, however, should be interpreted with caution due to the high degree of correlation between the variables Government is a minority shareholder and Government's $\%$ ownership as a minority shareholder. 
TABLE 7. Government's percentage ownership as a minority shareholder and the private benefits of control.

\begin{tabular}{|c|c|c|c|c|}
\hline Independent Variables & model 1 & model 2 & model 3 & model 4 \\
\hline Gvmnt is a minority shareholder & $\begin{array}{r}-65.39^{b} \\
(29.74)\end{array}$ & $\begin{array}{r}-55.34^{\mathrm{c}} \\
(27.53)\end{array}$ & $\begin{array}{r}-73.93^{\mathrm{b}} \\
(34.62)\end{array}$ & $\begin{array}{r}-68.32^{b} \\
(31.03)\end{array}$ \\
\hline Gvmnt's \% ownership as a min sholder & $\begin{array}{c}-0.43 \\
(0.88)\end{array}$ & $\begin{array}{c}-0.73 \\
(1.01)\end{array}$ & $\begin{array}{c}-0.85 \\
(0.99)\end{array}$ & $\begin{array}{l}-1.20 \\
(1.06)\end{array}$ \\
\hline Gvmnt is the largest shareholder & $\begin{array}{r}-66.65^{a} \\
(24.46)\end{array}$ & $\begin{array}{r}-64.70^{\mathrm{a}} \\
(21.16)\end{array}$ & $\begin{array}{r}-84.32^{b} \\
(32.26)\end{array}$ & $\begin{array}{r}-84.35^{\mathrm{a}} \\
(24.12)\end{array}$ \\
\hline Private placement & $\begin{array}{c}-37.70 \\
(25.29)\end{array}$ & $\begin{array}{c}-25.77 \\
(17.99)\end{array}$ & $\begin{array}{c}-33.40 \\
(24.46)\end{array}$ & $\begin{array}{r}-31.97^{c} \\
(20.64)\end{array}$ \\
\hline Privatization deal & $\begin{array}{c}-40.26 \\
(26.74)\end{array}$ & $\begin{array}{c}-36.67 \\
(25.09)\end{array}$ & $\begin{array}{c}-40.03 \\
(26.39)\end{array}$ & $\begin{array}{c}-42.36 \\
(21.44)\end{array}$ \\
\hline Absolute majority stake & $\begin{array}{c}3.19 \\
(28.23)\end{array}$ & $\begin{array}{c}4.39 \\
(26.54)\end{array}$ & $\begin{array}{c}-4.29 \\
(29.15)\end{array}$ & $\begin{array}{c}-6.99 \\
(25.41)\end{array}$ \\
\hline Foreign acquirer & $\begin{array}{c}-21.01 \\
(17.95)\end{array}$ & $\begin{array}{c}-29.54 \\
(18.42)\end{array}$ & $\begin{array}{c}-11.68 \\
(16.71)\end{array}$ & $\begin{array}{c}-20.93 \\
(17.40)\end{array}$ \\
\hline US crosslisting & $\begin{array}{c}-19.26 \\
(27.97)\end{array}$ & $\begin{array}{c}-17.59 \\
(22.67)\end{array}$ & $\begin{array}{c}-31.49 \\
(31.76)\end{array}$ & $\begin{array}{c}-28.01 \\
(26.06)\end{array}$ \\
\hline Another large shareholder & $\begin{array}{c}-16.50 \\
(26.62)\end{array}$ & $\begin{array}{c}-6.58 \\
(24.18)\end{array}$ & $\begin{array}{c}-23.00 \\
(26.98)\end{array}$ & $\begin{array}{c}-13.69 \\
(25.41)\end{array}$ \\
\hline Financial distress & $\begin{array}{c}-9.61 \\
(20.41)\end{array}$ & $\begin{array}{c}-3.40 \\
(19.05)\end{array}$ & $\begin{array}{c}-14.46 \\
(17.87)\end{array}$ & $\begin{array}{c}-13.91 \\
(18.17)\end{array}$ \\
\hline Mandatory tender offer Req & $\begin{array}{c}-5.36 \\
(18.64)\end{array}$ & $\begin{array}{c}-10.73 \\
(16.01)\end{array}$ & $\begin{array}{c}-18.26 \\
(20.31)\end{array}$ & $\begin{array}{c}-19.27 \\
(19.25)\end{array}$ \\
\hline Antidirector-rights-index & $\begin{array}{c}-5.54 \\
(8.13)\end{array}$ & & & $\begin{array}{c}-1.23 \\
(8.31)\end{array}$ \\
\hline Anti-self-dealing-index & & $\begin{array}{c}-69.03 \\
(42.10)\end{array}$ & & $\begin{array}{c}-74.16 \\
(54.44)\end{array}$ \\
\hline Rule of Law index & & & $\begin{array}{c}-7.00 \\
(4.83)\end{array}$ & $\begin{array}{c}-8.40 \\
(5.08)\end{array}$ \\
\hline Intercept & $\begin{array}{c}138.26^{\mathrm{a}} \\
(47.88)\end{array}$ & $\begin{array}{r}151.44^{\mathrm{a}} \\
(46.34)\end{array}$ & $\begin{array}{r}185.10^{\mathrm{a}} \\
(65.92)\end{array}$ & $\begin{array}{r}239.91^{a} \\
(75.51)\end{array}$ \\
\hline Adj. R-squared & 0.17 & 0.23 & 0.21 & 0.25 \\
\hline Number of observations & 54 & 54 & 52 & 52 \\
\hline
\end{tabular}

( Continued) 
TABLE 7. (Continued)

\begin{abstract}
Note: The dependent variable is the block premia calculated as the difference between the price per share paid for the control block and the price on the Exchange two days after the announcement of the control transaction, multiplied by the number of shares in the block and divided by the total market value of the firm's outstanding equity measured at the post announcement exchange price. Government is a minority shareholder if the government's ownership stake after the block trade is smaller than the ownership stake held by the acquirer of the controlling block. Government is the largest shareholder if the government's ownership stake after the block trade is larger than the ownership stake held by the acquirer of the controlling block. Government's \% ownership as a minority shareholder is an interaction term between the government is a minority shareholder dummy variable and the government's percentage ownership. In models 1 through 3 we introduce (sequentially) the anti-director, anti-self-dealing, and rule of law indices, which control for differences in the legal environments across countries. In model 4 we include all 3 indices simultaneously. The regressions are estimated by OLS. The standard errors (in parentheses below) are robust and clustered by country. All the numbers are expressed as percentages. a-significant at $1 \%$ level; b-significant at $5 \%$ level; c-significant at $10 \%$ level.
\end{abstract}

(2006)). In this section we investigate the hypothesis that minority government ownership in NPFs can act as a substitute for the lack of alternative mechanisms for minority shareholder protection. For example, the benefit of having the government as a minority shareholder, monitoring the controlling shareholder, would be much lower in the countries that have well developed legal and extra-legal institutions protecting the minority shareholders from the potential expropriation by the controlling shareholders. Therefore, we expect that the presence of the government as a minority shareholder will be more effective at curbing the private benefits of control in the countries with lower levels of minority shareholder protection, and less effective in the countries with higher levels of minority shareholder protection. Table 8 tests this hypothesis by estimating the interactions between the government is a minority shareholder dummy variable and the shareholder protection indices. ${ }^{20}$ Higher values of the interaction variables indicate the presence of the government as a minority shareholder in countries where the minority shareholders are better protected from the self-dealing actions of the controlling shareholders. We estimate the following regression equation:

20. The antidirector-rights, anti-self-dealing, and rule of law indices range from 0 to 6 , 0 to 1 , and 0 to 10 respectively. As described in the Appendix, higher values of the indices indicate higher levels of investor protection. 


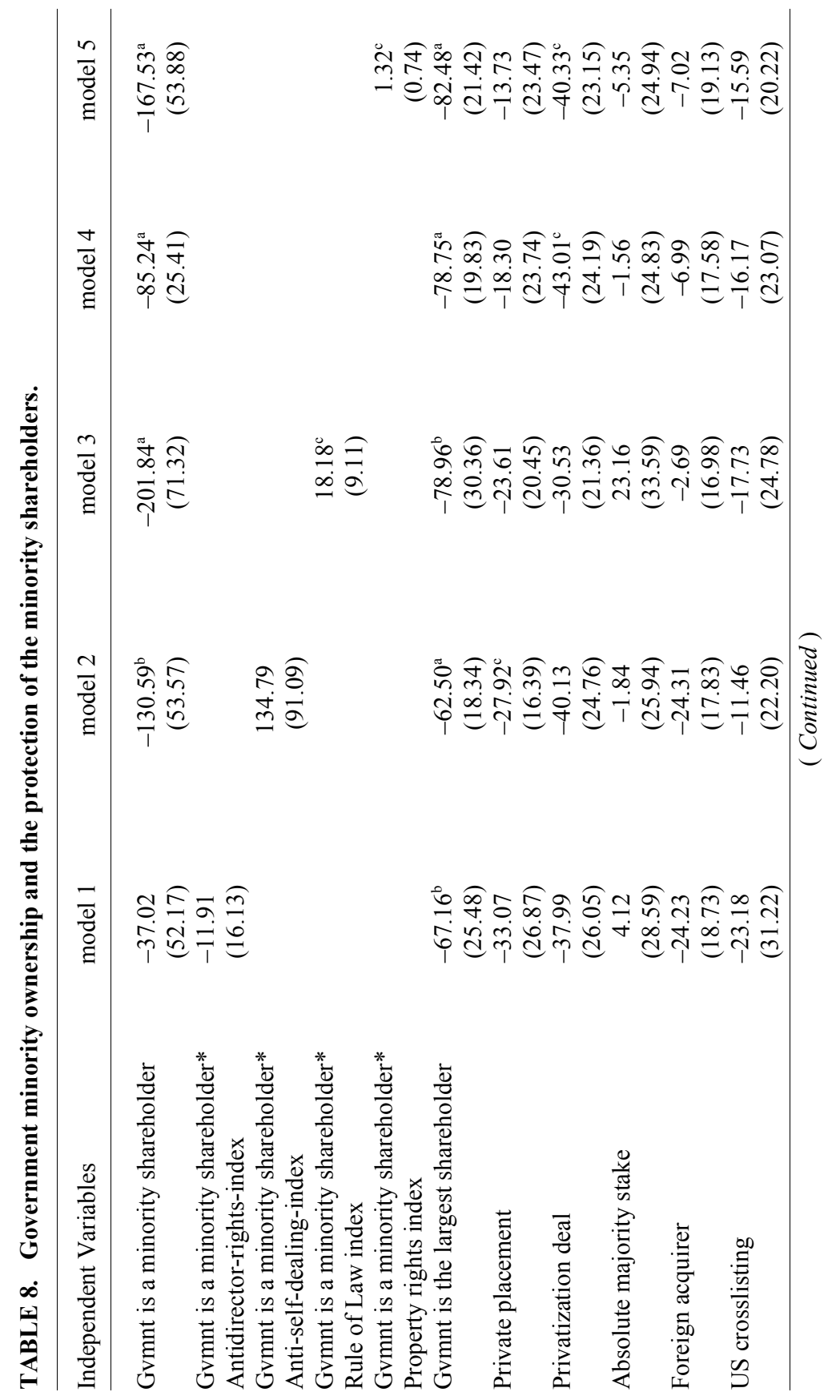




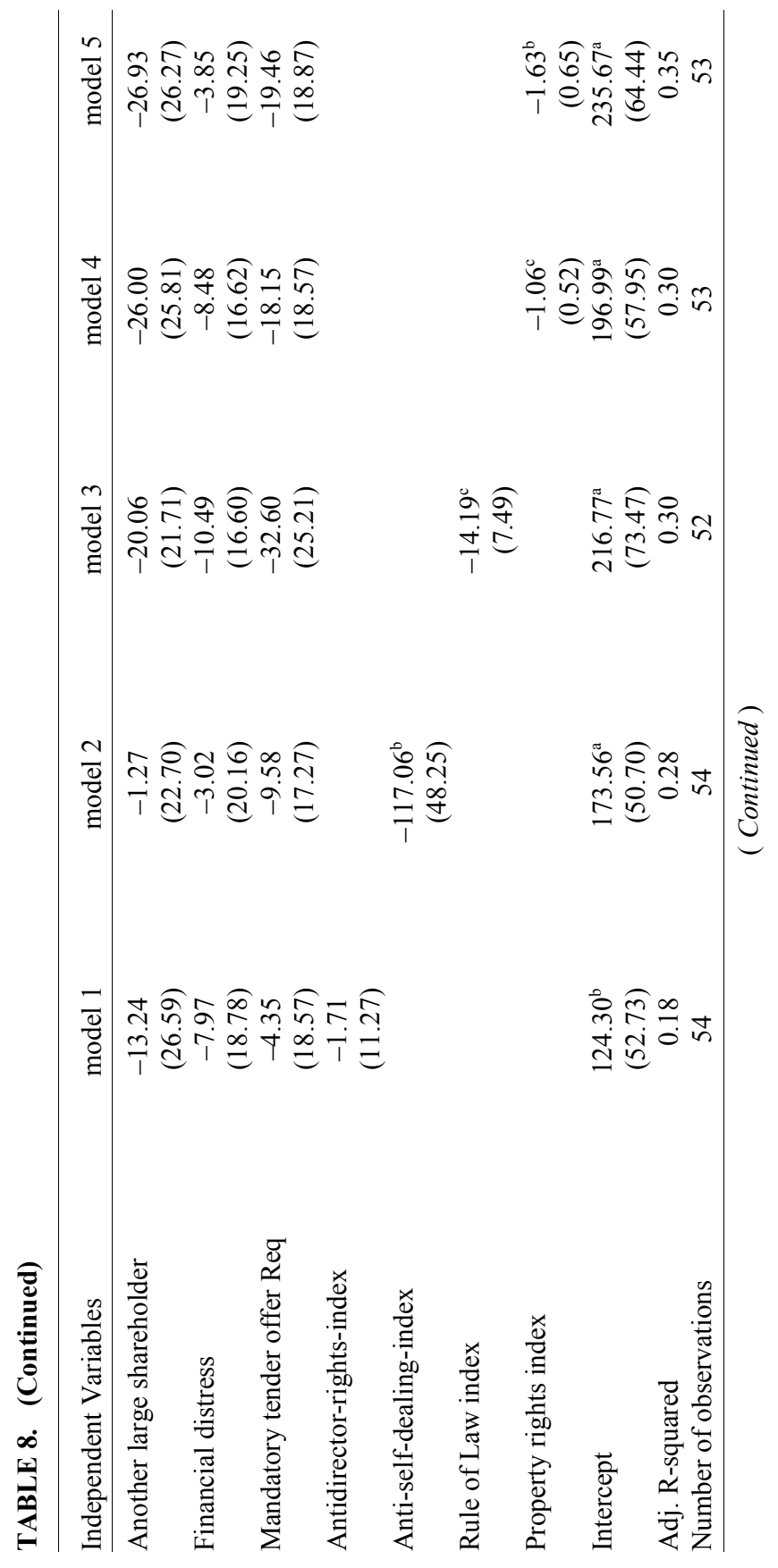




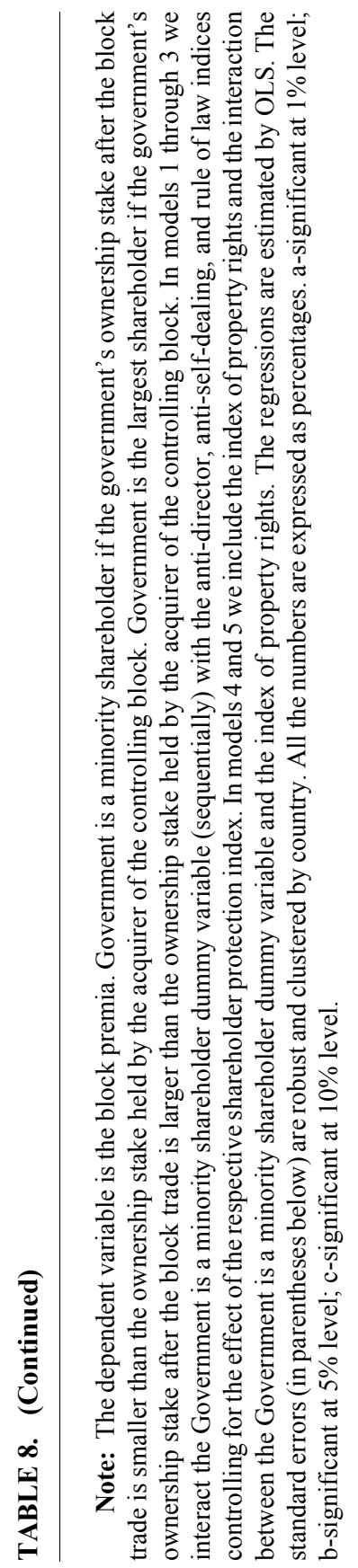


Block premium $=\beta_{0}+\beta_{1}$ Government is a minority shareholder $+\beta_{2}$ Government is a minority shareholder*shareholder protection indices $+\beta_{3}$ Government is the largest shareholder $+\beta_{4}$ Private placement $+\beta_{5}$ Absolute majority stake $+\beta_{6}$ Privatization deal $+\beta_{7}$ Another largeshareholder $+\beta_{8}$ Mandatory tender offer requirement $+\beta_{9}$ US crosslisting $+\beta_{10}$ Foreign acquirer $+\beta_{11}$ Financial distress $+\beta_{12}$ Investor protection indices $+\varepsilon$

Specifications 1 and 2 in table 8 show that the interactions between the government is a minority shareholder dummy variable and the antidirector-rights and the anti-self-dealing indices are not statistically significant. In model 3, however, we find that the interaction between the government is a minority shareholder dummy variable and the rule of law index is positive and significant. This evidence supports our hypothesis that the presence of the government as a minority shareholder is more effective at curbing the private benefits of control in the countries where the alternative mechanisms for shareholder protection, for example, through the legal system are less developed. For example, the presence of the government as a minority shareholder in New Zealand is associated with approximately 20 percent decrease in the private benefits of control while in Indonesia it is associated with a 130 percent decrease in the private benefits of control. ${ }^{21}$

In order to increase our confidence in the above findings, we examine another proxy for the overall quality of institutional development. In model 4 we test the effect of a widely used index of property rights on the ability of the controlling shareholders to extract private benefits of control. ${ }^{22}$ The negative and significant coefficient on the property rights index indicates that the countries that provide better protection of private property rights curb the ability of the controlling shareholders to extract private benefits of control. In model 5, we find

21. The values of the rule of law index for New Zealand and Indonesia are 10 and 3.98 respectively.

22. The property rights index is from the Index of Economic Freedom constructed by the Heritage Foundation. The index ranges from 0 to 100 with higher values of the index indicating better protection of private property rights. The index reffects the degree to which a country's laws protect private property rights and the degree to which the government enforces those laws. The index is available annually since 1995. For the years before 1995 we use the 1995 values of the index. 
that the estimated coefficient of the interaction between the government is a minority shareholder dummy variable and the property rights index is positive and significant. This result provides further support for the hypothesis that the presence of the government as a minority shareholder is more effective at curbing the private benefits of control in the countries which lack alternative mechanisms for shareholder protection.

Another issue that the above findings address deals with the effect of minority government ownership on the potential sources of private benefits of control. The three sources of private benefits of control are the psychological value of being in control, the consumption of perquisites, and the expropriation of the minority shareholders. The countries with lower scores on the rule of law and the property rights indices provide more opportunities for minority shareholder expropriation. Therefore, the findings that the presence of the government as a minority shareholder is more effective at curbing the private benefits of control in the countries with lower values of the rule of law and the property rights indices, where the potential for minority shareholder expropriation is higher, suggest that the minority government ownership reduces the minority shareholder expropriation component of the private benefits of control.

\section{Robustness}

A potential concern with our analysis is that the acquirers of the controlling blocks in companies where the government is a shareholder may pay less for their shares, because the government itself expropriates value from the firms or because government ownership adversely affects firm performance and hampers the ability of the new controlling shareholders to increase the value of the firm. These arguments may be valid in some cases, but they do not affect the results and implications of our study. We measure the private benefits of control with the block premium, which is calculated as the difference between the price per share paid by the acquirer of the controlling block and the price on the Exchange two days after the announcement of the control transaction. ${ }^{23}$

23. The rest of the measure multiplies the premium per share by the number of shares in the block and divides the result by the total market value of the firm's outstanding equity measured at the post announcement exchange price. 
The price per share paid by the acquirer of the controlling block reffects the sum of the cash flow benefits that the controlling shareholder expects to receive in proportion to his fractional ownership in the company and the private benefits that he expects to extract from his controlling position in the firm. On the other hand, the market price of the stock after the announcement of the block trade reflects only the cash flow benefits that the non-controlling shareholders expect to receive in proportion to their fractional ownership in the corporation, in the presence of the new blockholder. The block premium, therefore, reflects only the benefits that accrue exclusively to the controlling shareholders. Any effect of government ownership on firm performance and on the ability of the new controlling shareholders to increase the value of the firm will be reflected in the price of the stock on the exchange after the announcement of the control transaction, and therefore, will not influence our measure of the private benefits of control. This allows us to investigate the effect of the presence of the government as a minority shareholder on the ability of the controlling shareholders to extract private benefits of control without making any assumptions about the overall effect of government ownership on the value of the firm.

We also address the potential alternative interpretations of the block premia and examine the robustness of our findings. The most important alternative interpretation of the block premia is that they reflect systematic overpayments by the acquirers of the controlling blocks rather than private benefits of control. We employ the procedure from Dyck and Zingales (2004) to test the overpayment hypothesis. ${ }^{24}$

If the block premia arise from systematic overpayments, then the stock prices of the acquiring firms will react negatively to the announcement of the block trades. In our sample, we have 9 transactions involving publicly traded acquirers that have stock prices available in the Datastream database. Table 9 presents the analysis of the cumulative abnormal returns of the acquiring firms employing a 16-day event window ( $\mathrm{t}-8$ to $\mathrm{t}+7)$ to allow for relevant information about the transactions to be leaked in advance or to be incorporated with delay into the stock price. ${ }^{25}$ Panel A illustrates that the mean cumulative

24. Barclay and Holderness (1989) reject the overpayment hypothesis in their sample of U.S. block trades, and Dyck and Zingales (2004) reject it in their sample of international block trades.

25. Dyck and Zingales (2004) also employ the 16-day event window. 
TABLE 9. Does the control premium come from overpayment?

Cumulative abnormal returns of the acquirers from $t-8$ to $t+7$

A. All deals

\begin{tabular}{lc} 
Mean & 1.69 \\
Median & 0.62 \\
Min & -7.12 \\
Max & 13.80 \\
St. Dev & 7.33 \\
N. obs. & 9 \\
\hline
\end{tabular}

B. Different deal types

\begin{tabular}{lcc} 
& $\begin{array}{c}\text { Not a } \\
\text { privatization deal }\end{array}$ & Privatization deal \\
\hline Mean & 0.10 & 2.48 \\
Median & -6.38 & 2.05 \\
Min & -7.12 & -5.29 \\
Max & 13.80 & 8.45 \\
St. Dev & 11.87 & 5.23 \\
N. obs. & 3 & 6 \\
\hline
\end{tabular}

C. Different government ownership categories

\begin{tabular}{lccc}
$\begin{array}{c}\text { Deals where government } \\
\text { is not a shareholder } \\
\text { in the target firm }\end{array}$ & $\begin{array}{c}\text { Deals where government } \\
\text { is a minority shareholder } \\
\text { in the target firm }\end{array}$ & $\begin{array}{c}\text { Deals where government } \\
\text { is the largest shareholder } \\
\text { in the target firm }\end{array}$ \\
\hline Mean & 2.69 & 3.49 & -7.12 \\
Median & 0.62 & 3.49 & -7.12 \\
Min & -6.38 & 3.49 & -7.12 \\
Max & 13.80 & 3.49 & -7.12 \\
St. Dev & 7.55 & - & - \\
N. obs. & 7 & 1 & 1
\end{tabular}

Note: The table reports summary statistics for the cumulative abnormal returns of the companies acquiring the controlling blocks around the dates when the acquisitions of the controlling blocks are announced. We employ a window from eight days prior to the announcement to seven days after the announcement. We have 9 transactions involving publicly traded acquirers, which have stock prices reported in the Datastream database. All the numbers are expressed as percentages.

abnormal return for the 9 acquirers is positive and insignificant, which is evidence against the overpayment hypothesis. In panels $\mathrm{B}$ and $\mathrm{C}$ of table 9 we investigate whether the announcement effect is different in transactions where the government is involved either as the seller of the controlling block (in the case of privatization deals) or as a shareholder in the target firm. The results indicate that the average announcement 
effect is always positive (albeit insignificant) except in deals where the government is the largest shareholder in the target firm. ${ }^{26}$

Another alternative interpretation of the block premia, especially in underdeveloped markets, is that the acquirer of the controlling block has superior information about the target, and the information about the transaction is incorporated slowly into the target's stock price. To test this hypothesis we follow Dyck and Zingales (2004) and re-estimate the private benefits of control using the price on the exchange thirty rather than two days after the announcement of the block trade, and repeat all the tests. ${ }^{27}$ The main findings remain unchanged. ${ }^{28}$

Our sample consists of 54 observations. Therefore, it is possible that a few outliers are driving the main results. To address this possibility, we winsorize the block premia at the 10 percent level. Alternatively, we drop all observations where the block premia are less than -40 percent or greater than 100 percent. Our main results are robust to these alternative specifications. ${ }^{29}$

We also examine whether our results are specific to a particular time period. We include indicator variables for observations during the periods from 1990 to 1995,1995 to 2000, and 2000 to 2005. None of the time indicators attain statistical significance and they do not affect our main findings. The results are also robust to including country fixed effects, regional dummies, industry controls, or controls for the identity of the acquirer (private, government, subsidiary, or public corporation).

In all of our regressions we included a dummy variable indicating whether the target firm is in financial distress as proxy for the seller's bargaining power. Since the government is the seller of the shares in several of our block transactions (the case in privatization deals) we could also include a control variable for whether the government is in distress. ${ }^{30}$ Financial or political distress can affect the government's

26. An important caveat to the results reported in table 9, and especially in Panel C of that table, is that the very small sample size might affect the validity of our findings.

27. Dyck and Zingales (2004) also use a 30-day window to test (and ultimately reject) the "superior information hypothesis" in their study of the private benefits of control.

28. The results are not reported, but are available upon request.

29. The results are also robust to dropping all observations from China, which has a very unique institutional environment, and all observations where there is another large shareholder (other than the government).

30. We thank the referee for suggesting this additional analysis. 


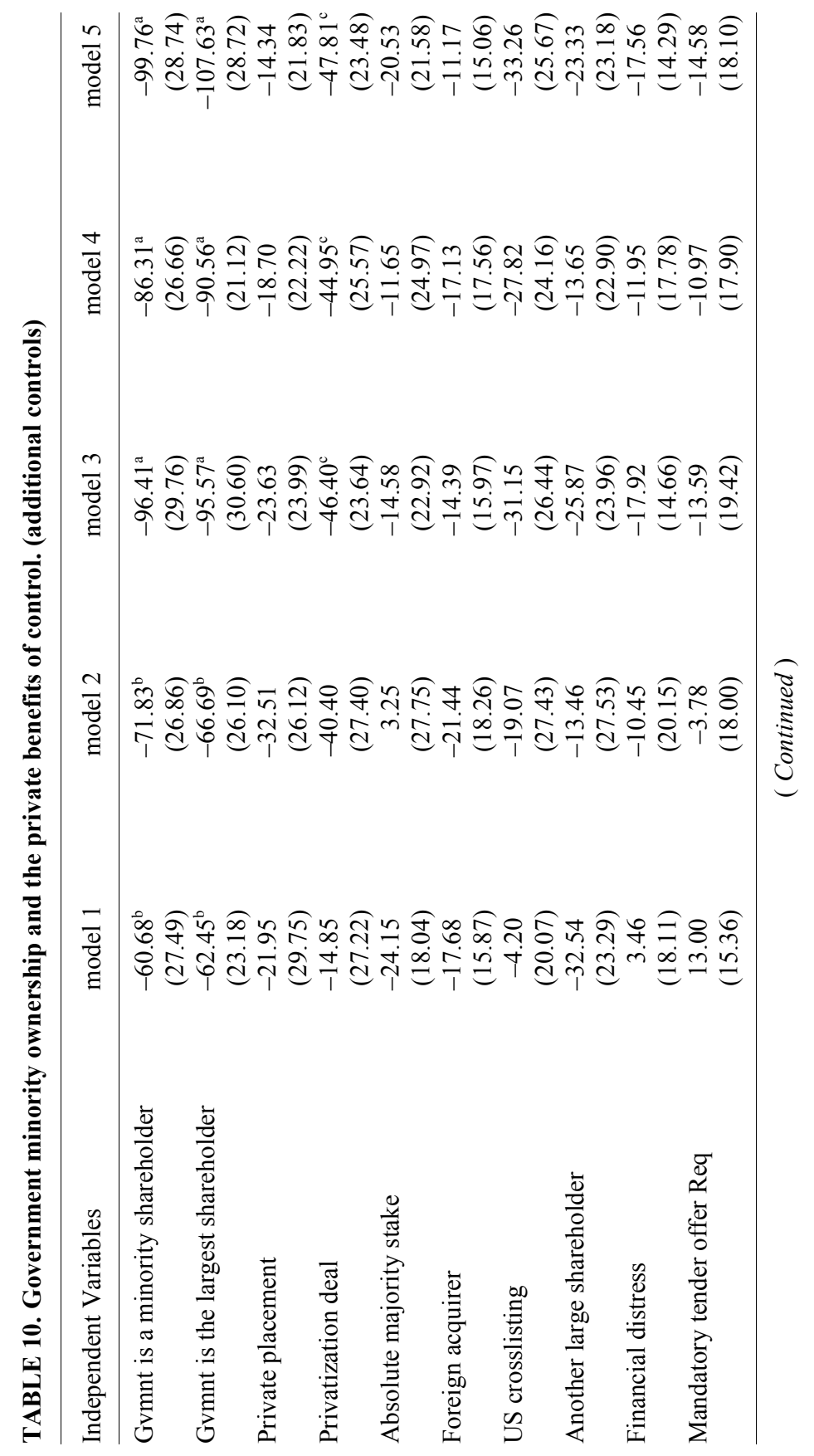




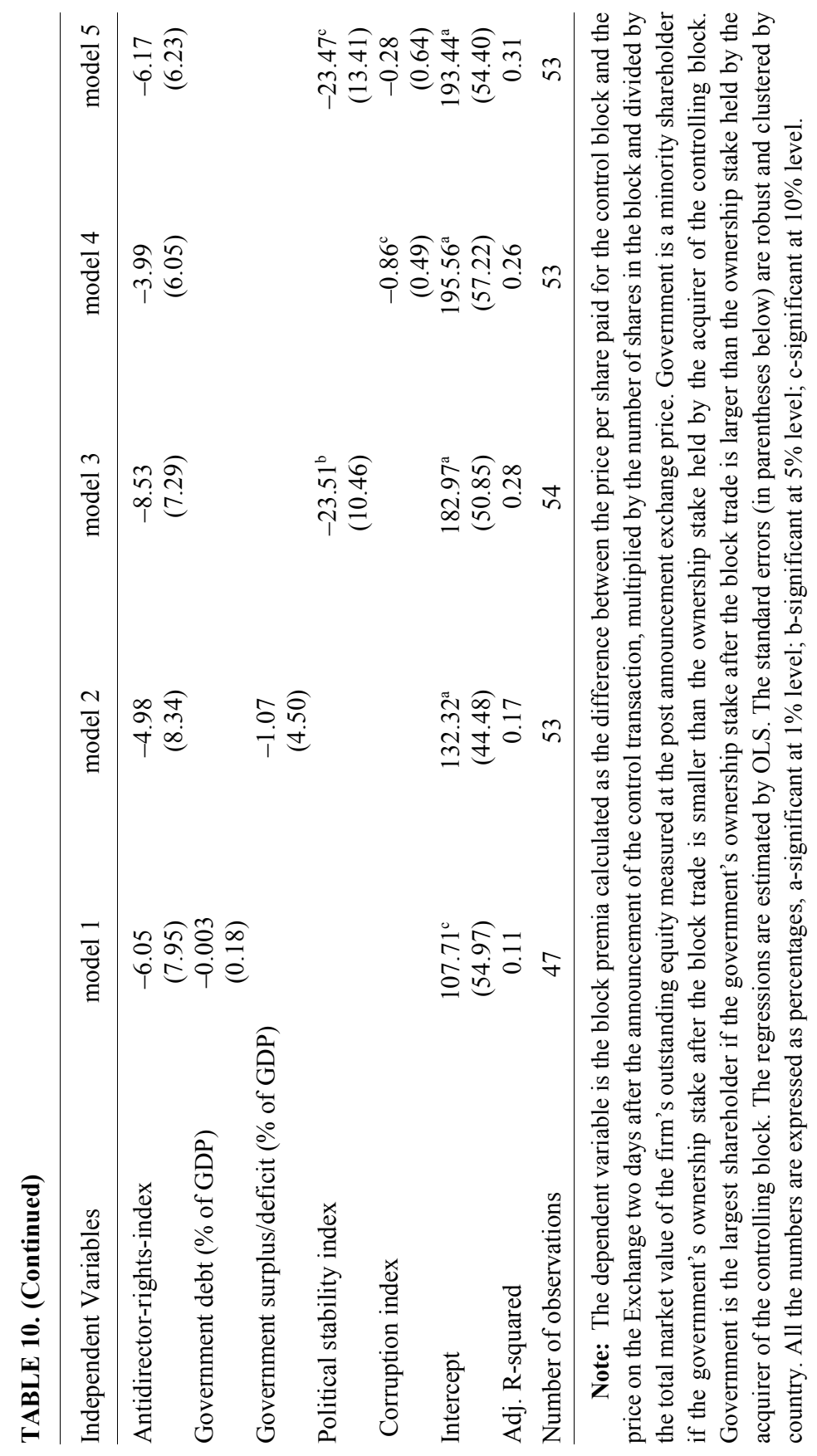


bargaining power in privatization deals, as well as the government's ability and incentives to protect the minority shareholders in newly privatized firms. In table 10 we re-estimate model 1 from table 6 by including sequentially the government's debt-to-GDP ratio, surplus or deficit, and political stability index. ${ }^{31}$ The results from the first three specifications in table 10 indicate that our main findings are robust to the inclusion of controls for government distress, and that the private benefits of control are lower in countries with more politically stable governments. The last two columns in table 10 also document that our main findings are not affected by the inclusion of a corruption index which can potentially affect the private benefits of control and the government's ability to effectively monitor controlling shareholders in newly privatized firms.

Finally, our main findings are robust to excluding transactions where the government's ownership stake exceeds 20,15 , or 10 percent of the firm's outstanding equity. Dropping these observations significantly reduces the degrees of freedom in the regressions, but increases our confidence in the result that the presence of the government as a minority shareholder curbs the ability of the controlling shareholders to extract private benefits of control.

\section{Conclusion}

This paper examines the effect of minority government ownership on the ability of the controlling shareholders in privatized firms to extract private benefits of control. In a sample of newly privatized firms (NPFs) we document that the presence of the government as a minority shareholder curbs the ability of the controlling shareholders to extract private benefits of control. Furthermore, we find that the presence of the government as a minority shareholder is more effective at curbing the private benefits of control in countries that have weaker institutions protecting the rights of investors. This suggests that minority government ownership is a substitute for the lack of alternative mechanisms for minority shareholder protection.

Prior studies document that the extent of the private benefits of control adversely affects security market development. In this context our findings are consistent with the privatizing governments' stated objectives of developing a liquid national stock market and an "equity

31. These variables are defined along with their sources in the appendix. 
culture". The privatizing governments in countries with lower levels of minority shareholder protection, which are attempting to foster security market development and prevent the tunneling of assets and profits out of the NPFs, may find it optimal to retain a minority ownership stake in the NPFs until adequate legal and extra-legal institutions are developed to protect the minority shareholders from the potential expropriation by the controlling shareholders.

We are not advocating government ownership as a solution to corporate governance failures. Such a cure would be worse than the disease. We attempt, however, to illustrate that the optimal government ownership stake in NPFs can, in some instances, be different from zero.

Accepted by: Prof. P. Theodossiou, Editor-in-Chief, February 2014

\section{Appendix I. Definitions and sources of variables used in the paper}

\begin{tabular}{|c|c|}
\hline Variable & Definition \\
\hline Block premia & $\begin{array}{l}\text { The block premia are calculated as the } \\
\text { difference between the price per share paid } \\
\text { for the control block and the price on the } \\
\text { Exchange two days after the announcement } \\
\text { of the control transaction, multiplied by the } \\
\text { number of shares in the block and divided } \\
\text { by the total market value of the firm's } \\
\text { outstanding equity measured at the post } \\
\text { announcement exchange price. Source: } \\
\text { Securities Data Corporation (SDC) and } \\
\text { Datastream. }\end{array}$ \\
\hline
\end{tabular}

Government is a minority shareholder

Government is the largest shareholder
A dummy variable that equals one if the government's ownership stake after the block trade is smaller than the ownership stake held by the acquirer of the controlling block, and zero otherwise. Source: Company annual reports, Woldscope, and company web sites.

A dummy variable that equals one if the government's ownership stake after the block trade is larger than the ownership stake held by the acquirer of the controlling block, and zero otherwise. Source: Company annual reports, Woldscope, and company web sites. 


\begin{tabular}{|c|c|}
\hline Variable & Definition \\
\hline Private placement & $\begin{array}{l}\text { A dummy variable that equals one if the } \\
\text { block trade is a private placement, and zero } \\
\text { otherwise. Source: Securities Data } \\
\text { Corporation (SDC). }\end{array}$ \\
\hline
\end{tabular}

Privatization deal

Absolute majority stake

Foreign acquirer

U.S. crosslisting

Another large shareholder

Financial distress

Mandatory tender offer Requirement
A dummy variable that equals one if the block trade is a privatization deal (i.e. the government is the seller of the shares), and zero otherwise. Source: Securities Data Corporation (SDC).

A dummy variable that equals one if the block trade involves more than 50 percent of the firm's outstanding equity, and zero otherwise. Source: Securities Data Corporation (SDC).

A dummy variable that equals one if the acquirer of the controlling block is domiciled in a country other than the firm's country of incorporation, and zero otherwise. Source: Securities Data Corporation (SDC).

A dummy variable that equals one if the firm is cross-listed in the United States, and zero otherwise. Source: Thomson ONE Banker.

A dummy variable that equals one if the firm has another large non-government shareholder who owns more than 20 percent of the firm's outstanding shares, and zero otherwise. Source: Company annual reports, Woldscope, and company web sites.

A dummy variable that equals one if the firm's earnings per share are zero or negative in the year of the block trade or the year preceding the block trade, and zero otherwise. Source: Datastream.

A dummy variable that equals one if the block trade triggers a mandatory tender offer requirement, and zero otherwise. Source: Dyck and Zingales (2004). 


\begin{tabular}{|c|c|}
\hline Variable & Definition \\
\hline Antidirector-rights-index & $\begin{array}{l}\text { An index ranging from } 0 \text { to } 6 \text { with higher } \\
\text { values of the index indicating higher levels } \\
\text { of investor protection. Source: La Porta et } \\
\text { al. (1998) and Pistor, Raiser, and Gelfer } \\
(2000) \text {. }\end{array}$ \\
\hline
\end{tabular}

Anti-self-dealing-index

Rule of law index

Property rights index

Corruption index

Political stability index

Government debt (\% of GDP)

Government surplus/deficit (\% of GDP)
An index ranging from 0 to 1 with higher values of the index indicating better protection of minority shareholder rights. Source: Djankov et al. (2008).

An index ranging from 0 to 10 with higher values of the index indicating better legal protection of investor rights. Source: La Porta et al. (1998) and Pistor, Raiser, and Gelfer (2000).

An index ranging from 0 to 100 with higher values of the index indicating better protection of private property rights. The index is available annually since 1995 . For years before 1995 we use the 1995 values of the index. Source: Index of Economic Freedom (www.heritage.org/index).

An index ranging from 0 to 100 with higher values of the index indicating lower levels of corruption. The index is available annually since 1995 . For the years before 1995 we use the 1995 values of the index. Source: Index of Economic Freedom (www.heritage.org/index).

An index ranging from -2.5 to 2.5 with higher values of the index indicating more stable governments. The index is available annually since 1996. For the years before 1996 we use the 1996 values of the index. Source: Worldwide Governance Indicators (www.govindicators.org).

Total central government debt as percent of GDP. Source: World Bank Development Indicators.

Central government surplus or deficit as percent of GDP. Source: World Bank Development Indicators. 


\section{References}

Aghion, P., and Bolton, P. 1992. An incomplete contracts approach to financial contracting. Review of Economic Studies 59: 473-494.

Atanasov, V. 2005. How much value can blockholders tunnel? Evidence from the Bulgarian mass privatization auctions. Journal of Financial Economics 76: 191-234.

Atanasov, V.; Ciccotello, C.; and Gyoshev, S. 2006. Learning from the general principles of company law for transition economies: The case of Bulgaria. Journal of Corporation Law 31: 1004-1033.

Aussenegg, W. 2000. Privatization versus private sector initial public offerings in Poland. Multinational Finance Journal 4: 69-99.

Barclay, M. J., and Holderness, C. G. 1989. Private benefits from control of public corporations. Journal of Financial Economics 25: 371-395.

Barclay, M. J.; Holderness, C. G.; and Sheehan, D. P. 2001. The block pricing puzzle. Working paper.

Biais, B., and Perotti, E. 2002. Machiavellian privatization. American Economic Review 92: 240-258.

Boubakri, N.; Cosset, J.-C.; and Guedhami, O. 2005. Liberalization, corporate governance and the performance of privatized firms in developing countries. Journal of Corporate Finance 11: 767-790.

Boutchkova, M. K., and Megginson, W. L. 2000. The impact of privatization on capital market development and individual share ownership. Financial Management 29: 67-77.

Choi, S.-D., and Nam, S.-K. 1998. The short-run performance of IPOs of privately- and publicly-owned firms: International evidence. Multinational Finance Journal 2: 225-244.

Choi, S.-D., and Nam, S.-K. 2006. The long-run stock performance of privatization IPOs. Multinational Finance Journal 10: 223-250.

Djankov, S.; La Porta, R.; Lopez-de-Silanes, F.; and Shleifer, A. 2008. The law and economics of self-dealing. Journal of Financial Economics 88: 430-465.

Doidge, C. 2004. U.S. cross-listings and the private benefits of control: Evidence from dual-class firms. Journal of Financial Economics 72: 519-553.

Dyck, A., and Zingales, L. 2004. Private benefits of control: An international comparison. Journal of Finance 59: 537-600.

Efron, B., and Tibshirani, R. 1986. Bootstrap methods for standard errors, confidence intervals, and other measures of statistical accuracy. Statistical Science 1: 54-77.

Hertzel, M., and Smith, R. 1993. Market discounts and shareholder gains for placing equity privately. Journal of Finance 48: 459-485.

Jensen, M., and Meckling, W. 1976. Theory of the firm: Managerial behavior, agency costs and ownership structure. Journal of Financial Economics 3: 
$305-360$.

Johnson, S.; La Porta, R.; Lopez-de-Silanes, F.; and Shleifer, A. 2000. Tunneling. American Economic Review 90: 22-27.

Jones, S. L.; Megginson, W. L.; Nash, R. C.; and Netter, J. M. 1999. Share issue privatizations as financial means to political and economic ends. Journal of Financial Economics 53: 217-253.

Kogan, L. 2010. Small-sample inference and bootstrap. MIT, Sloan.

La Porta, R.; Lopez-de-Silanes, F.; and Shleifer, A. 1999. Corporate ownership around the world. Journal of Finance 54: 471-517.

La Porta, R.; Lopez-de-Silanes, F.; Shleifer, A.; and Vishny, R. W. 1997. Legal determinants of external finance. Journal of Finance 52: 1131-1150.

La Porta, R.; Lopez-de-Silanes, F.; Shleifer, A.; and Vishny, R. W. 1998. Law and finance. Journal of Political Economy 106: 1113-1155.

La Porta, R.; Lopez-de-Silanes, F.; Shleifer, A.; and Vishny, R. W. 2000a. Agency problems and dividend policies around the world. Journal of Finance 55: 1-33.

La Porta, R.; Lopez-de-Silanes, F.; Shleifer, A.; and Vishny, R. W. 2000b. Investor protection and corporate governance. Journal of Financial Economics 58: 3-27.

La Porta, R.; Lopez-de-Silanes, F.; Shleifer, A.; and Vishny, R. W. 2002. Investor protection and corporate valuation. Journal of Finance 57: 1147-1170.

Lease, R. C.; McConnell, J. J.; and Mikkelson, W. H. 1983. The market value of control in publicly-traded corporations. Journal of Financial Economics 11: 439-471.

Megginson, W. L.; Nash, R. C.; Netter, J. M.; and Poulsen, A. B. 2004. The choice of private versus public capital markets: Evidence from privatizations. Journal of Finance 59: 2835-2870.

Megginson, W. L., and Netter, J. M. 2001. From state to market: A survey of empirical studies on privatization. Journal of Economic Literature 39: 321-389.

Nenova, T. 2003. The value of corporate voting rights and control: A cross-country analysis. Journal of Financial Economics 68: 325-351.

Omran, M. 2004. Performance consequences of privatizing Egyptian state-owned enterprises: The effect of post-privatization ownership structure on firm performance. Multinational Finance Journal 8: 73-114.

Pistor, K.; Raiser, M.; and Gelfer, S. 2000. Law and finance in transition economies. Economics of Transition 8: 325-368.

Shleifer, A., and Vishny, R. W. 1997. A survey of corporate governance. Journal of Finance 52: 737-783.

Zingales, L. 1995. What determines the value of corporate votes? Quarterly Journal of Economics 110: 1047-1073. 